\title{
State Sphere Shift into Public Sphere: E-Musrenbang Surabaya City
}

\author{
Eddy Christijanto \\ Ph.D Student in Faculty of Social and Political Sciences, Airlangga University Surabaya \\ nanikoye@gmail.com
}

\begin{abstract}
This research was conducted to find out how a space formed by the government (state sphere) has the potential to turn into a public sphere which is deliberative because of the involvement of information technology. This research was carried out on the use of information technology in the implementation of electronic development planning meetings (E-musrenbang) in the City of Surabaya, East Java, Indonesia. This research was conducted qualitatively using a critical approach. The data processed and analyzed were obtained from community leaders in four villages in Surabaya. As a result, this study shows that the internet has provided opportunities for people to make the state sphere as a public sphere where people can act further and more freely as citizens to voice their aspirations, opinions, and ideas. As such, indirectly the participation of the community to be involved in regional development can be pushed to a higher level.
\end{abstract}

Keywords: state sphere; public sphere; E-musrenbang; deliberative; participation

\section{Introduction}

Community participation is needed in forming an effective government. Community participation is a process in which problems, needs, and community values are accommodated in government decision making. This shows that there is a two-way interaction between the community and the government as a decision-making institution so that the decisions made are the best decisions supported by the community. As stated by Creighton, that community participation will produce the best decision so that it can minimize the chances of not being well implemented. Participation in decision making will make individuals united as citizens by training them to think for the public good rather than personal interests. Mansuri \& Rao said that such community participation, in addition to building capacity for collective action referred to by modern social experts as "agencies", can also develop the ability of the community to take control of the country by being responsible for its actions in influencing decisions that affect life.

Participation is inseparable from the element of involvement. Engagement requires a media that is used as a means to show involvement. Participation is a form of social transformation that is used to understand and develop a strategy. Participation is closely related to social interaction. In this regard, participation actually aims to increase the involvement of other parties in order to provide an opportunity to speak out in determining policies that will affect their lives. For this reason, a means is needed that allows all the wishes of the community to be conveyed properly through the public sphere. The public sphere, according to Habermas, is a special means to transmit information and influence those who receive it. Newspapers, magazines, radio and television are examples of public space 
media. Community involvement is a context that frees individuals to express their thoughts with the principles of politeness, openness, and equality even though they have not been able to fully guarantee the quality of the involvement. The city of Surabaya as one of the smart city pioneers in Indonesia has built a systematic IT system for the benefit of e-government or public service interests. This is very necessary to do because along with the high population in a city including big cities like Surabaya, there is no other choice but to adopt and develop a smart city. The reason for developing a smart city (smart city) is quite basic because the high number of population can have a negative and positive impact on the development of the city.

The positive impact if the city is conducive so that it can design activities and services, so that the design of the city makes its population more productive. On the contrary, the negative impact is that if you cannot do the design of activities and good services to the community, the community will become unproductive As is well known, under the Surabaya City Government, Surabaya has become a 'friendly' city startup by launching the Surabaya Start program (incubation program and acceleration of digital creative startups). Surabaya has also developed e-government facilities. The application and development of e-government facilities carried out by the Surabaya City Government is highly appreciated and should be used as an example for other cities as International Smart City. To accommodate and improve the process of community participation in the City of Surabaya, there is a public space that can be utilized by the community and provided or facilitated by the Government in the concept of e-government.

Figure 1. Surabaya City E-Government Structure

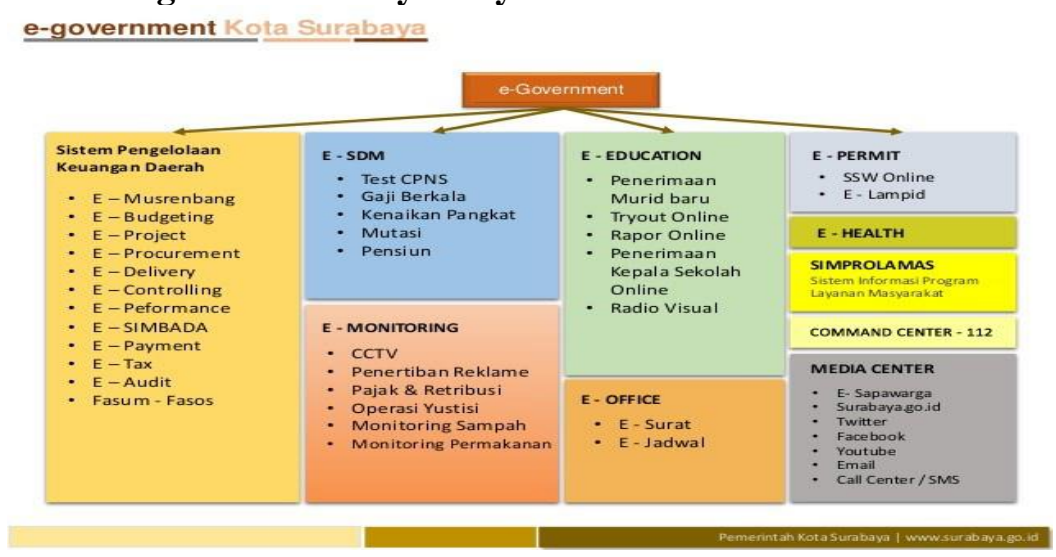

The Public Space facilitated by the Government, one example is Musrenbang. Musrenbang is a forum between stakeholders in order to develop regional development. With the aim of realizing regional development in order to increase and equalize community income, employment opportunities, field work, improve access and quality of public services and regional competitiveness. In E-Musrenbang which utilizes the internet, the government is no longer a provider and implementer, but rather acts as a facilitator and catalyst of the dynamics of development, so that from planning to implementation, the community has the right to be involved and provide input and make decisions, in order to fulfill the rights - the basic principle, one of them is through the musrenbang process. Even today as seen in the government structure, the Surabaya City Government has developed an E-Musrenbang development process that is based on online with the people who enter into the E-Musrenbang 
application. This is intended to provide certainty to the citizens of the proposed development plan. With this application, the community can monitor and supervise the proposed development in the region, and can understand whether the proposed proposal is approved to be realized or not. This is different from the implementation of MSrenbang when it has not been implemented through electronic systems. At that time the Musrenbang was carried out only to abort the obligations as mandated in the Ministerial Regulation. The process of implementing musyawah Development planning starts with a discussion or deliberation in the Neighborhood Community Unit (RW) by involving the RW and Chairperson of the Neighborhood Unit (RT) and community leaders, religious leaders, PKK or representatives of women and youth leaders or Karang Tarunayang led by the RW Chair. In the deliberation process the proposals were discussed which were the priorities of the RW environment that would be taken in pre-Musenbang in the kelurahan. After the formulation of the results of the deliberations which became the priority of the next development proposal, the Pra Musrenbang forum was held in the kelurahan. But before the pre-Musrenbang proposal from RW was entered into the Musrenbang application by the RW Chair and the village staff. Then it was carried out pre-Musrenbang in January in the kelurahan area by involving community leaders, religious leaders, women's representatives (PKK), youth representatives (Karang Taruna), representatives from the RW attended by the Board of Village Community Empowerment Institutions (LPMK), the Village Guard Patara ( Babinsa), Chief of Guidance for the Management of Community Order (Babin Kamtibmas) led by the Lurah. This forum resulted in an agreement on priority proposals that will be brought to the Development Planning Consultation (Murenbang) forum in the Subdistrict by making an Event Report on the Pre-Village Musrenbang. Before the implementation of the Musrenbang e, the community felt that the process of the Village Musrenbang and the subdistrict Musrenbang was a ceremonial forum of the National and Regional development planning systems. However, with this e-Musrenbang, the community feels that the development proposals submitted to the Surabaya City Government are valued and called upon, even though it is adjusted to the integrated system of related OPD activities. This can be seen from the following table:

Table 1. Evaluation of Community Participation through the Surabaya City E-Musrenbang

Source: Bappeko Kota Surabaya, 2017

\begin{tabular}{|c|c|c|c|c|}
\hline \multirow{2}{*}{ Item } & \multicolumn{4}{|c|}{ Year } \\
\cline { 2 - 5 } & 2014 & 2015 & 2016 & 2017 \\
\hline RW proposal & 1898 & 2519 & 1753 & 2829 \\
\hline Community Proposal & - & - & 601 & 395 \\
\hline Proposal is processed & 1895 & 2032 & 2167 & 2517 \\
\hline Proposed approval & 1509 & 1523 & 1769 & 1939 \\
\hline \% Approval & $79,50 \%$ & $60,46 \%$ & $75,15 \%$ & $60,14 \%$ \\
\hline
\end{tabular}

Based on the table above it can be seen that during the period 2014 to 2017 there were proposals included in the approved E-Musrenbang system. In 2014 as many as $79.5 \%$ of proposals were approved, then in 2015 there was a decrease in the proposals approved to be $60.46 \%$. Continuing in 2016 there was an increase in the approval of the proposal amounting to $75.15 \%$ and in 2017 again decreased by $60.14 \%$ of the proposals that were approved. Based on that data, it appears that in 2017 the percentage of proposals approved was the smallest compared to other years. From these data, researchers made the basis for the implementation of this research writing. However, the weakness of this Musrenbang is that there is a budget 
ceiling per kelurahan around Rp. 1 billion to 1.5 billion in accordance with the population and area of the kelurahan due to the limitations of the Surabaya City Budget. This causes many development proposals that are equally urgent and cannot be proposed because of the limitations of the Budget ceiling. culvert from village to primary channel. Likewise with the RW Chair or community leaders who do not have the ability to ICT or technology, the City of Surabaya provides facilities for every RW to be given free internet networks. In addition, a Broadband Learning Center (BLC) was also built to provide free ICT skills training to RW Chairmen and community members who could not. The success of the Surabaya City Government is not spared from the support of Information and Communications Technology (ICT). Besides helping the government in the development of community services, the development of Information and Communications Technology (ICT) also enhances better community involvement. Email and Online Conversations make interaction between citizens and government more efficient. Blogs and Wikis are used as citizens to spread whatever they want to convey. The Online Forum, Virtual Discussion Room (social media), electronic juries and electronic pools make it easier for the government to gather the best public opinion. In the future cyber democracy, especially the internet, not only to increase community involvement, but also to create a new paradigm by promoting total community participation.

\section{Public Sphere and Deliberation Democracy in Surabaya City E-Musrenbang}

The e-Musrenbang process in the city of Surabaya has been running since 2009 based on the kelurahan where the proposals of the community through the head of the RW and the Head of the RT are sent to the kelurahan for further input into the E-Musrenbang application. Since 2012, village-based applications have been changed to RW-based. Thus, the RW Chair has the obligation to enter the proposed development plan by utilizing the given RW username and password. Therefore, RW administrators are required to be able to understand IT and the community can monitor the progress of proposals submitted through the head of the RW. For this reason the Surabaya City Government provides Internet facilities in each RW for free. Normatively, the E-Musrenbang process series begins with the inclusion of proposals on the website by the RW. Before being included, the proposals should ideally be agreed upon with the heads of RT. After all proposals were submitted by the RW leaders, the next musrenbang was held at the kelurahan level which was attended by RW leaders in each kelurahan and community leaders who were leaders of groups in each kelurahan. For example, the PKK group, Karang Taruna, Farmers Group, and so on. In the musrenbang at the kelurahan level, all proposals that have been put on the website are re-discussed and verified with the village head as a facilitator who provides places and other needs. If there is a deadlock in the discussion discussion, the village head is expected to be a mediator so that a joint agreement is made on what proposals will be submitted to the next stage. Some considerations that determine whether a proposal is worthy of submission or not, including the value of the budget, the impact that may be caused, and whether the location where the proposal will be realized has been handed over to the City Government or not.After an agreement and proposals have been agreed together, the next stage is musrenbang at the subdistrict level. At this stage what happens is the process of verification of proposals by the subdistrict. Then, after all proposals are verified, proceed to the SKPD Forum stage. Here the village representatives will also meet with the delegates or leaders of the SKPD-SKPD related 
to the proposals that have been verified. This meeting is important because in the end, if all proposals have been approved, the SKPD will be the party that ensures the implementation of these proposals. Based on the results of research and interviews with several informants during data extraction in four villages, namely Babatan Village and Jajar Tunggal Village in Wiyung District, and in Rungkut Kidul Village and Medokan Ayu Village, Rungkut Subdistrict, there were many dynamics in the community participation process. First, information technology support in the implementation of e-Musrenbang in Surabaya city received a positive response from the community represented by the informants in this study.

They stated that the implementation of e-Musrenbang had helped them to directly monitor the progress or progress of each proposal they submitted earlier. The existence of the internet through the e-Musrenbang website does not necessarily eliminate forums that are always held every year at the Musrenbang which previously took place face-to-face or conventional. Forums to determine what ideas will be proposed in e-Musrenbang continue from the RW level to the city level. This forum was held one of them because of the limited budget value, which is Rp. 1 billion per kelurahan. With a limited budget, residents must adjust the proposals they submit so that they do not exceed the value of the available budget. Although there was an argument over because of the limited budget, the informants praised the E-Musrenbang system because it made things more transparent. The use of information and communication technology in the implementation of Musrenbang in Surabaya City has sufficiently increased community participation. In addition to being supported by internet facilities, the growth of participation is also supported by equality with each other among the people involved in the implementation of e-Musrenbang. However, on the other hand, high participation can also be hampered by the apathy and pragmatism of citizens who feel that their aspirations are impossible to fulfill through e-Musrenbang because of the limited budget ceiling provided by the Surabaya City Government for each village. In other words, the motivation to get something for each group is an important factor in increasing participation.

It's just that, in the context of implementing e-Musrenbang, the high level of motivation is hindered by the domination of the city government represented through budget policy and city development policies, namely by limiting the budget ceiling of Rp. 1 billion per kelurahan and limiting the type of proposal. In addition, it is also seen that despite the EMusrenbang application which further facilitates the process of channeling aspirations, Surabaya residents also still need a face-to-face forum and deliberation to discuss development issues in their environment. Therefore, although it cannot yet become a fully public space, E-Musrenbang has succeeded in becoming a complement and providing new dynamics in the series of development processes in Surabaya. Growing public participation due to the involvement of information technology in the implementation of the Surabaya city E-Musrenbang reinforces Supelli's (2010) view that the internet is not only allowing people to see the world, but also allows them to be, inhabit, and act in it. From this view, virtual communities (cyber community) and cyberspace also represent physical spaces.

\section{Deliberative Democracy in the Implementation of E-Musrenbang}

Simple deliberation process can be interpreted as a joint decision-making process or consensus that is not based solely on the number of votes or voting-centric, but from open (talk-centric) dialogues. In the deliberation process efforts are made to change the way of 
thinking and the way of thinking of others through persuasive methods, not through coercion and manipulation. Therefore, in the deliberation process, every participant in the public space must be exposed to new information, ideas and arguments."Deliberation as a social process is distinguished from other kinds of communication in that delibrators are amenable to changing their judgments, preferences, and views during the course of their interactions, which involve persuasion than coercion, manipulation, or deception. (Dryzek, 2002: 1)

In a deliberative public space, there are several criteria that must exist. First, inclusion, which means that the space or forum is open to citizens. With these preconditions, all personal backgrounds such as education, employment, gender, religion, race, etc., are ignored. This is as stated by Han, Hamlin and Hamlin (2015: 1) "The priciples of inclusion and equality assert that deliberation must be open and accessible, and that everyone should be given an opportuniyu to participate.", or, the principles of inclusion and equal rights state that deliberation must be open and accessible, and everyone should be given the opportunity to participate. Based on the information stated by the informants in this study, face-to-face forums, especially those taking place at the kelurahan level, can be attended by all representatives of the community without considering their educational, religious, occupational, ethnic and racial background, and identity. other cultural identities. However, it was stated above that those present there were representatives of citizens who ideally carried out the mandates of the citizens they had visited. Therefore, here will arise the question whether the principle of representative or representativeness can be considered as a form of inclusiveness? With this statement, even though in the implementation of the deliberation forum that took place during the series of E-Musrenbang implementation involved the representatives of the citizens, it did not necessarily make the forum considered not inclusive. Moreover, in practice that is in line with its ideal conditions, before the discourse that brings together the representatives of the citizens, there has been an interaction between each citizen representative - in this case generally the RW chairman — with RT heads and other community groups. This interaction is carried out ahead of the face-to-face forum at the kelurahan level with the aim of exploring proposals from citizens that will be proposed in the E-Musrenbang process. The interaction between the Chairperson of the RW and the Heads of RTs did not always take place in formal forum forms such as meetings or deliberations. In its implementation in the four villages that are the location of the study, communication between RWs and RT heads and other residents is also carried out through informal meetings and through social media groups such as WhatsApp they form. Through a group consisting of community leaders, ahead of the commencement of the E-Musrenbang implementation, the RW Chair asked the RT heads to make proposals that would be submitted to E-Musrenbang and in accordance with the needs of their respective RTs. Likewise in the Rungkut Kidul Village. Ahead of the implementation of E-Musrenbang, Lurah officials made use of the WhatsApp group which consisted of local community leaders and reminded the RW leaders to explore inputs from residents regarding the proposals to be submitted to E-Musrenbang. In addition to the kelurahan level, the principle of representation is also applied when the implementation of E-Musrenbang has moved to the stage of the District Musrenbang Forum.

At this stage the number of representatives of the citizens sent was far less, generally the chairman of the LPMK and several chairmen of the RW. But in this stage, the interaction that took place was between residents and representatives of the government, namely the subdistrict. In this phase, the forum takes place to verify the proposals that have been entered into 
the E-Musrenbang online application and determine whether these proposals can be accepted and proceed to the next stage or not. Therefore, at this stage there is generally not enough going on in the debate between citizens. Even if later there is a discrepancy between the expectations of the people and the results of verification, it is generally directly discussed and decided by the village delegates present. Even though in the face-to-face forums that take place at the kelurahan, sub-district, and SKPD forums, those present as participants are citizen representatives, but through the support of information technology in the implementation of E-Musrenbang, citizens can have direct access to get involved, at least to question and comment on proposals that have been submitted, approved or realized. As explained earlier, it is facilitated through the feedback features available in the E-Musrenbang online application.

To use it, Surabaya residents only have to log in using the Population Registration Number (NIK). The existence of this feature shows that the Surabaya City Government really wants and gives opportunities to its citizens to participate in the development and the programs and activities that take place in their respective environments. The policy to include NIK in its own use is an appropriate policy because the online application of E-Musrenbang is actually built for the benefit of Surabaya citizens themselves. In addition, remembering in cyberspace, a person's identity can become so blurry because that's where they have the ability to establish a virtual identity, including anonymity. This was explained by Karlina Supelli in his article entitled Public Space of the Maya World which was published in the book Public Space: Tracking "Democratic Participation" from Policy to Cyberspace. Many users only display pseudonyms without describing physical characteristics or original characters. Every citizen is free to choose things he wants or doesn't want to show to the public, without other citizens being able to check or question it. Residents can also submit opinions or comments on anything without the need for special expertise and almost without the need to account for it. The internet is far more stressful than the authenticity of information and its accuracy. People have enough to comment and can still present themselves as anonymous creatures. He can send information on behalf of anyone and from anywhere, without the need to side with certain moral positions, because the goal is simply to comment. "(Supelli, 2010: 340-341) Another criterion for determining whether a discourse has taken place deliberately is openness. What is meant by openness is that the discourse is open to new ideas and new arguments as long as they are rational. Because they are open to new ideas and new arguments, dialectically, those who are involved in the discourse must also have the freedom to convey all their ideas, arguments, or aspirations. Regarding the openness, Habermas stated this: "Moreover, because there is no criterion independent of the argumentative process, one can judge only from the participant's perspective whether these demanding presuppositions have been sufficiently fulfilled in a given case. This by itself warrants an openness to the possibility that provisionally justified views might have to be revised in the light of new information and arguments. Deliberation refers to a certain attitude toward social cooperation, namely, that of openness to persuasion by reasons referring to the claims of others as well as one's own. The deliberative medium is a good faith exchange of views - including participant's reports of their own understanding of their respective vital interests" (Habermas, 1996 : 179, 273). Discussing the disclosure criteria, in the series of EMusrenbang implementation in Surabaya City, the author saw that the representatives of citizens involved in the deliberation process had the freedom to express their aspirations. 
From this perspective, it can be said that openness has been realized in the implementation of E-Musrenbang in Surabaya City. In addition to this (the freedom of expressing aspirations) has been acknowledged and stated explicitly by the informants who have been interviewed, also because it was revealed that in the deliberation process especially at the kelurahan level - it is common to have fierce arguments when each citizen representative seeks to encourage proposals that they carry can be approved for. In this argumentation, new arguments generally appear and persuade others who are exposed to arguments to change their minds. Next, because the Musrenbang implementation in Surabaya City has involved the mediation of information and communication technology, the criteria for openness must also be measured by the extent to which citizens understand and can access the online application of E-Musrenbang. The ability to access this, in addition to depending on the skills that are owned, also depends on the presence or absence of access. Related to this, the informants in this study stated that the problem of accessing the internet did not become an obstacle. Apart from having the ability to operate the internet, either through computers, laptops, tablets, or cell phones, the available infrastructure, namely the internet network, they can enjoy anywhere. Next, the criteria for other deliberative democracy are neutrality and power relations. In this case the neutrality in question is what must be shown by the holder of power. According to Habermas, in a deliberation process that often involves argumentation, it must be neutral towards all arguments circulated in the discourse. "In particular - and this is the bone of contention - the power holder must remain neutral with respect to competing and mutually incompatible conceptions of the good life: "No reason is a good reason if it requires the power holder to assert: (a) that his conception of the good is better than that asserted by any of his fellow citizens, or (b) that, regardless of his conception of the good, he is intrinsically superior to one or more of his fellow citizens." Neutrality means, to begin with, the priority of justice over the good, and hence the fact that questions of the good life recede behind questions of justice. (Habermas, 1996 : 309). From the research that has been done, the author finds that in the entire series of E-Musrenbang implementation in Surabaya City, communication between citizens and the government is an important part other than the discourse that takes place between the representatives of citizens. Moreover, according to some informants who are representatives of citizens, Surabaya City Government and its representatives are still considered not optimal in communicating with citizens. As a consequence, there are still people who feel they do not know anything about E-Musrenbang, while on the other hand, what is produced from it will be directly enjoyed or impact on citizens. Complaints related to poor communication between residents and representatives of the Surabaya City Government were stated by informants from the Rungkut Kidul village.

Chairperson of Rungkut Kidul Village LPMK, Yudi Gunawan, said that the barriers to communication between citizens and government representatives, namely the village head and the sub-district head, appeared a lot when all proposals in E-Musrenbang were verified until the final stage and began to be realized or being realized. The informant judged that the residents lacked information about the follow-up of the proposals that had been approved, especially those related to physical development. When the proposal begins to be realized, for example, there are not many community leaders in the environment involved or at least not given notice. Moreover, in a physical project that took place there, project implementers often did not install boards explaining the details of the project. For informants, this made it difficult for them to participate in supervision and made them feel as if they were merely 
objects. Regardless of the truth of the statements of various parties, the top-down or top-down information deadlock is likely to occur or be felt by citizens. Aside from the fact that socialization is considered not optimal, the experience and knowledge of the citizens are also diverse so that the information provided is not acceptable in accordance with what is expected by those who provide information. This basically can be overcome or minimized through the innovation of the Surabaya city government which involves the mediation of information and communication technology in the implementation of E-Musrenbang. As explained earlier, through the E-Musrenbang online application, if citizens feel they lack information needed from the village head or sub-district head, they can still convey this through the EMusrenbang online application that provides feedback features. Likewise from the perspective of the Surabaya City Government, internet mediation in the musrenbang implementation enables them to explore more information and input from the community regarding the needs of programs, activities, and development in their respective environments. Through internet mediation in the implementation of musrenbang, the Surabaya City Government opens the door of communication for its citizens and considers them as equal partners to realize development targets. From this explanation, it can be stated that the mediation of information and communication technology in the series of E-Musrenbang implementation in Surabaya has helped overcome the obstacles in communication, both cultural constraints and physical constraints such as distance. In addition, the involvement of information and communication technology has also provided the ability for citizens to do more in development in their environment. This is in line with what the following Schmidt and Cohen explained: "Being able to do more in cyberspace will make the real world more efficient. When digital connectivity reaches the corners of the earth, new users will use it to fix markets, systems and behavior that are not widely efficient, in the most developed or backward societies. This efficiency and productivity will produce extraordinary results. Especially in developing countries, whose growth and progress have been hampered for years due to the isolation of technology and bad policies. Now, with just a few facilities, they can do more. "(Schmidt and Cohen (2014: 2) Furthermore, the final criteria for deliberative democracy in the implementation of E-Musrenbang in the city of Surabaya is Decision Making Capacity. In this regard, the important questions include: (1) how is the implementation of decision-making in the E-Musrenbang implementation series in Surabaya City, (2) does the Surabaya city government provide enough space for the community to express their aspirations, and (3) whether the time inside Decision making is satisfactory? As explained earlier, the implementation of E-Musrenbang in Surabaya City took place in several stages. In the series of implementation, the decision-making mechanism takes place in a variety of ways. In the deliberations that took place in the kelurahan, decisions were made through a discourse process between representatives of citizens. During the process, sharp arguments are commonplace because the representatives of the citizens are trying to fight for the interests related to their respective environments. In the author's view, in this stage deliberative democracy occurs because what is agreed upon there is the result of a rational interaction process. In this stage, the lurah as a representative of the Surabaya City Government did indeed attend and carry out his function as a facilitator. As a facilitator, the lurah did not have the authority to make decisions that were contrary to the wishes of the representatives of the citizens involved in the forum. In the case of the lurah first distributing a form containing a list of things that cannot be proposed through E-Musrenbang because it is classified as a city 
problem, it must be interpreted that it is not in the interests of the lurah itself, but in order to enforce the legal order, which is a legitimate rule so in the context of E-Musrenbang in the City of Surabaya it is a limit that cannot be surpassed by those involved in the deliberation process. Of course, the existence of these limitations can be interpreted differently by those involved in the deliberation process to decide on the proposed E-Musrenbang that took place at the kelurahan level. On the one hand, it seems to be something that limits citizens in determining the direction of development in their respective environments. But on the other hand, it does not reduce their freedom to express their ideas in the space. Moreover, in the end they also have to make rational decisions, including by comparing the budget value of the proposals they submit with the available budget ceiling. Furthermore, even though the criteria for deliberative democracy are realized in the implementation of E-Musrenbang, this does not necessarily make it a purely public space controlled by the public. In this case, the Surabaya City Government still has control over how the discourse patterns occur there, namely through a budget policy that sets a budget ceiling of Rp 1 billion per village. However, the control also does not automatically lose its freedom to express ideas. The control of the Surabaya City Government in implementing E-Musrenbang, on the other hand also shows that there is still a hegemony which according to Antonio Gramsci can also be considered as a form of power repression. It's just that, the difference is that the hegemony is achieved through directed and systemic discourse mechanisms so that the public feels that they are not victims of repression, but voluntarily accepts the government's decision. Quoted from Situmorang (2016), Gramsci stated that hegemony means mastering through moral and intellectual leadership. Consensus in hegemony appears as an active commitment, based on the superodinative views and legitimate positions. In other words, in a public space that is formed by the government itself, hegemony always occurs and even though the public is not always aware of its existence. If possible, this is similar to the architectural or physical public space in the form of parks and squares created by the government. In these public areas, citizens are given the freedom to do the things they want, including expressing their ideas openly. But at the same time they also realized that the actions he did could not violate the norms and laws that apply.

\section{Conclusion}

The use of Information Technology by the Surabaya City Government in implementing E-Musrenbang has opened clogged faucets in the process of community participation. The change in the State Sphere to Public Sphere through Information Technology has resulted in the creation of the Musrenbang process through e-Musrenbang. 1) freedom to express ideas, 2) Openness of Government and Society, 3) Equal rights to all communities in the proposal process, 4) no coercion in community aspirations, 5) There is an exchange of knowledge between the Government and the Community even though it is not maximal, 6) The Neutrality of the Power Relationship of the Surabaya City Government, 7) Inclusiveness means that representatives of the RW Chair represent the name of the citizens, because it is not possible for all citizens to attend. In addition, it can also be concluded that in the implementation of E-Musrenbang in the City of Surabaya there are public buildings 'which serve as an arena for the public to determine solutions to the problems they face. But this public space is not something that arises because of the full initiative of the citizens, but by 
the encouragement given by the Surabaya city government. The Surabaya city government itself encourages and supports the emergence of the public space because it has an interest that is to encourage community participation in the development process. Judging from the perspective of Habermas (1987: 196), the involvement of the city government such as conducting mediation is a form of system colonization of the world of life (lifeworld). This colonization feels even bigger when the E-Musrenbang implementation series starts entering the stages of the kecamatan deliberation. At these stages, the rights of citizens to make decisions increasingly eroded. On the other hand, in the name of the limits of the proposals that have been set from the beginning and the limited budget ceiling available, the representation of the Surabaya city government at this stage has greater power and practices of power to determine what proposals can pass verification. From the description, it can be said that it is quite impossible to make E-Musrenbang which is a state sphere completely transformed into a public sphere as long as there are power resources that are controlled by the government so that the public depends. Although E-Musrenbang cannot fully become a public space owned by citizens, the use of the internet has provided a new perspective in relation to citizen participation in it. In relation to the public space formed in the series of EMusrenbang implementation, the internet can be said to be outside public space. Although it is outside the building of public space, but the internet has the ability to strengthen the building, namely by giving more people the opportunity to be involved in it. In the sense, citizens who are not directly involved or not who are appointed as representatives of the citizens, can still provide their participation by giving ideas, comments, and criticism of proposals that have been included in the E-Musrenbang. In other words, the presence of information and communication technology has complemented the Musrenbang building created by the government. Regardless of whether Surabaya residents have known the opportunities they have to participate by utilizing the E-Musrenbang application, but the features available in the online application of E-Musrenbang have opened up opportunities for the realization of several criteria of communicative action at this stage, namely equality of rights and freedoms. to express opinions, and no coercion. While related to other criteria, namely the realization of consensus, this certainly cannot happen in the virtual domain, namely when the public uses the online application E-Musrenbang to express ideas. This happens because the form of interaction that occurs in it is not a deliberative discourse practice, but rather a two-way interaction between citizens and the Surabaya city government mediated by the internet. Thus, any conclusions and responses that arise as a result of these interactions cannot be immediately claimed as a consensus that represents the public as a whole or at least directly gets approval from the public.

\section{References}

Bohman, James. 1996. Public Deliberalism: Pluralism, Complexity and Democracy. Cambridge: MIT Press.

Callahan, Kathe. 2007. Elements of Effective Governance: Measurement, Accountability, and Participation. New York: CRC Press Taylor and Francis Group.

Creighton, James L. 2005. The Public Participation Handbook: Making Better Decisions Through Citizen Involvement. San Fransisco-California: Jossey-Bass (A Willey Imprint). 
Dryzek, John S. 2002. Deliberative Democracy and Beyond: Liberals, Critics and constastations. Oxford: Oxford University Press

Habermas, S. Lennox \& F. Lennox. 1995. The Public Sphere: An Encyclopedia Article." New German Critique, no. 3 p. 49-55.

Habermas, Jurgen. 1989. The Structural Transformation of The Public Sphere. Cambridge: MIT Press.

Hardiman, Budi. 2009. Demokrasi Deliberatif. Yogyakarta: Kanisius.

Hickey, Samuel and Giles Mohan. 2004.Participation: From Tyranny to Transformation? Exploring New Approaches to Participation in Development, London, Zed Books;

Hohendahl, P \& P. Russian. Jürgen Habermas: "The Public Sphere" (1964). New German Critique No. 3. p. 45-48.1974

Hye Han, Soo \& Hamlin, William Schenck \& Hamlin, Donna Schenck. 2015. Inclusion, Equality, and Discourse Quality in Citizen Deliberations on Broadband. Journal of Public Deliberation Vol 11 issue 1 ( $p p$ 1-24)

Mansuri, Ghazala \& Vijayendra Rao. 2013. Localizing Development A Conceptual Framework for PArticipation. Washington D.C.: The World Bank.

Mardikanto, Totok \& Soebiato. 2013. Pemberdayaan Masyarakat Dalam Prespektif. Kebijakan Publik. Bandung: Alfabeta.

Mardiyanta, Antun. 2011. Kebijakan Publik Deliberatif: Relevansi dan Tantangan Implementasinya." Korespondensi Vol. 24, No. 3 Hal. 261-271.

McLuhan, Herbert Marshall. 1962. The Guttenberg Galaxy. Toronto \& New York: University of Toronto Press.

Oktara, Diko. Menko Darmin Sebut Surabaya Contoh Smart City di Indonesia. 2017. Diakses dari https://nasional.tempo.co/read/ 876933/menko-darmin-sebut-surabaya-contohsmart-city-di-indonesia.

Ramualdus, Sandy. Menopang Surabaya Sebagai Pelopor Smart City. 2017. Diakses dari http://www.indonesiasatu.co/detail/menopang-surabaya-sebagai-pelopor-smart-city

Rosenberg, Shawn. 2007. Deliberation, Participation and Democracy: Can The People Goven? New York: Palgrave McMillan, Hampshire.

Supelli, Karlina. 2010. Ruang Publik Dunia Maya, dalam Ruang Publik: Melacak "Partisipasi Demokratis" dari Polis Sampai Cyberspace. Yogyakarta : PT Kanisius

Zheng, Yueping. 2017. Explaining Citizens' E-Participation Usage: Functionality of EParticipation Applications. SAGE Administration \& Society Vol. 49(3) p. 423-442 